\title{
Climate Change Impact on Social and Economic Sectors in Mongolia
}

\author{
Altanbagana Myagmarsuren ${ }^{1, *}$, Saruul Galtbayar ${ }^{1}$ \\ ${ }^{1}$ Institute of Geography and Geoecology, Mongolian Academy of Sciences, Ulaanbaatar, Mongolia \\ *Corresponding author. Email: altanbaganam@mas.ac.mn
}

\begin{abstract}
Nomadic pastoralism is a herder-pastoral-livestock system. These components are interlinked to sustain each other and each contains some level of adaptive and resilience capacity. Thus, it is necessary to consider all components of pastoralism in a systematic manner. As a result of climate change, intensity and frequency of droughts and dzud are increasing and they have negative impacts on the socio-economic development. The purpose of this study is to describe how climate change is affecting herder's livelihood, livestock loss, and gross domestic product (GDP) growth in agriculture sector and migration in Mongolia. Number of herders and households, rural poverty, migration to urban areas from rural areas, production of agricultural sector, annual GDP growth of agricultural sector, livestock numbers and losses, drought and dzud indexes were used to analyse the impact of climate change on herder-pastoral-livestock system. In 2000-2003, drought-dzud disaster affected over 90 percent of Mongolian territory and caused 11.17 million livestock loss. In 2009-2010, 80 percent of territory was affected and 10.32 million livestock were lost. The number of herder households decreased by 22.5 thousand and 24 thousand during 1999-2002 and 2009-2010 dzud respectively. After the occurrence of two times dzud, the production of agricultural sector in total GDP decreased by 44 percent in 2002 and 35 percent in 2010. The unemployment rate reached 4.6 percent in 2001 and poverty in rural area reached $43.4 \%$ in 2003. It was 33 percent increase compared to 1998. In 1995-2013, 122.1 thousand people migrated to Ulaanbaatar city due to the 1999-2002 and 2009-2010 dzuds. This is 26 percent of the total migrants and can be defined as "climate refugees". In Mongolia, there is a strong connection between "climate change-poverty" and "climate change-migration" because of their unique life style, settlement, economic and ecosystem characteristics.
\end{abstract}

\section{Keywords: Climate change, Drought-dzud impact, Livestock loss, Poverty, Migration}

\section{INTRODUCTION}

Mongolia is a vast country comprised of mountains, rangelands, and desert landscapes with scarce water resources. Due to geographical location, topography features and socio-economic conditions, climate change impact is severe in Mongolia. Near surface temperature and its annual mean over Mongolia have increased by 2.24 degrees between 1940-2015 which is 2-3 times higher than the world average [1]. At the same time, extreme climatic events are increasing. Drought and dzud (severe winter conditions causing livestock loss) are the most damaging hazards that directly or indirectly effect the socio-economic situation in Mongolia. Since 1940, both drought and dzud conditions have increased [2]. During 1940-2010, the drought intensity increased by around 2 percent annually, and the drought-dzud intensity (integrated dzud index) increased by 0.6 percent annually [3].

As a consequence of climate and socio-economic changes during last two decades, vulnerability of Mongolia's pastoral social-ecological systems has increased. Resilience theory in Mongolian context is regeneration and renewal of any system that has the capacity to maintain systematic functions even with external factors [4]. Nomadic pastoralism is a herderpastoral-livestock system. These components are interlinked to sustain each other and each contains certain level of adaptive and resilience capacity [5]. Thus, it is necessary to consider all components of pastoralism in a systematic manner. There is a lack of scientific research analysing the herder-pastoral- 
livestock system from the socio-economic perspective as a whole. The purpose of this study is to describe how climate change is affecting herder's livelihood, livestock loss, GDP growth in agriculture sector and migration in Mongolia.

\section{METHODS}

The systemic approach was taken to analyze causes and consequences of drought-dzud occurrences and socio-economic changes in Mongolia. National level socio-economic data and environmental data such as number of herders and households, rural poverty, migration to urban areas from rural areas, production of agricultural sector in total GDP, annual growth of agricultural sector, livestock numbers and losses, drought and dzud indexes. The research was conducted with top-down approach and conducted review of existing papers, data analysis and causal analysis.

\section{RESULTS}

\subsection{The impact of the drought-dzud on the socio-economy}

Figure 1 shows integrated dzud index and number of livestock loss converted to sheep heads during 1990-2014. Integrated dzud index combines both dzud and drought index and describes the intensity of dzud [6]. Dzud disaster affected over 90 percent of total territory of Mongolia in 2000-2002 and over 80 percent in 2009-2010.

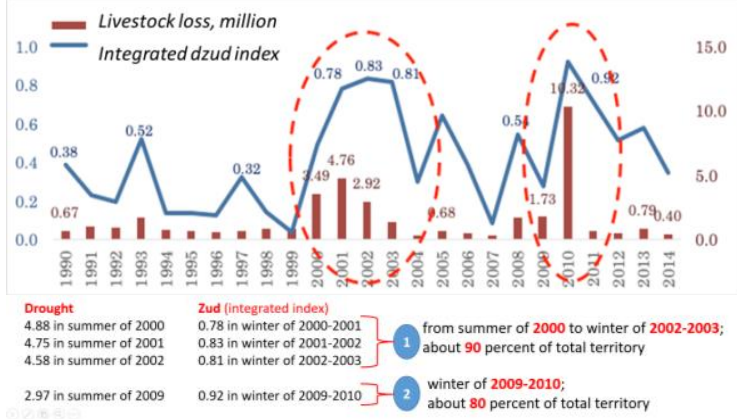

Figure 1. Drought and integrated dzud index and livestock loss index [7]

At the national level, livestock loss was higher for the years with dzud occurrences. During 2000-2003, both integrated dzud index and livestock loss was high, and 11.17 million livestock were lost. This phenomenon was repeated in 2009-2010. The dzud index and livestock loss increased to 0.92 and 10.32 million respectively. Figure 2 shows the result of correlation analysis of livestock loss and integrated dzud index during 1990-2014. The correlation coefficient was 0.69 meaning there is a statistically significant relationship between the dzud occurrence and the livestock loss. This indicates that the dzud conditions are directly related to livestock loss.

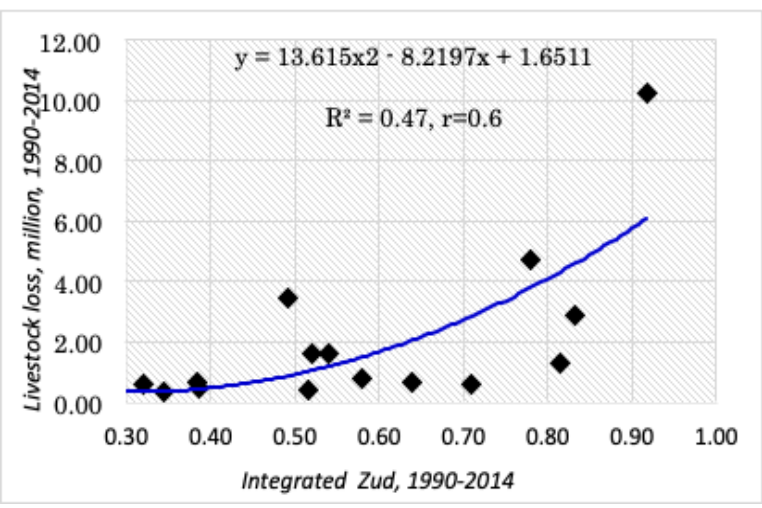

Figure 2. Correlation of integrated dzud index and livestock loss nationwide [7]

Figure 3 shows the aimag level livestock loss in sheep head during dzud years. In 2000-2002, most aimags except 5 were affected by dzud and lost more than 0.5 million sheep head each. Bayankhongor, Zavkhan and Uvurkhangai aimags suffered the biggest loss of livestock which was 2.14-2.66 million sheep head. During the dzud of 2009-2010, Uvurkhangai and Arkhangai aimags lost the highest number of livestocks followed by Zavkhan, Khuvsgul, Uvs, Govi-Altai, Bayankhongor and Dundgobi aimags.

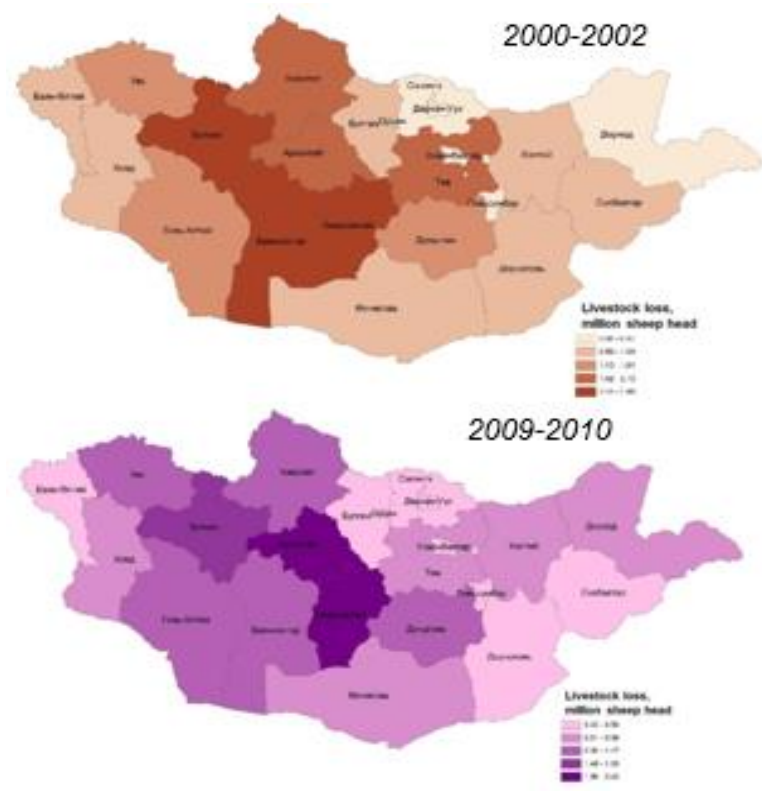

Figure 3. The number of livestock lost during the dzud year by animal head in each aimags [8]

Dzud is causing a decrease in the number of herders in rural areas because livestock is the main source of 
income and livelihood for herder households. Figure 4 shows number of livestock loss in sheep head and number of herder household during 1995-2020. Since public livestock were transferred to private property, the number of herder households has increased and reached 191.5 thousand in 2000 which was 35 percent of total household in Mongolia. The number of herder households decreased by 22.5 thousand and 24 thousand during 1999-2002 and 2009-2010 dzud respectively. After the occurrence of two times dzud, in 2012, number of herder households decreased to 146.1 thousand which is $13 \%$ of total households. Decreased number of herders implies that dzud has significantly negative impact on herder livelihood and agricultural production.

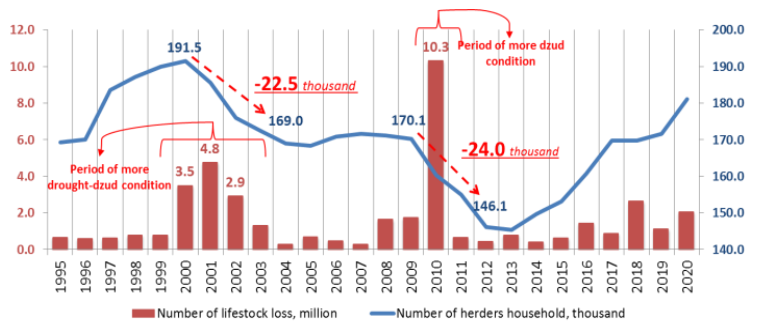

Figure 4. Trend of Livestock loss and Number of Herder's household, (1995-2020)

Pastoral livestock has an important role in Mongolian society and economy. The pastoral livestock sector is the second largest economy sector and constitutes more than $80 \%$ of agricultural production. From the employment point of view, a large number of people work in the pastoral livestock sector. Figure 5 shows the annual IN TOTAL GDP growth rate, annual GDP growth rate of agriculture sector and production of agricultural sector in total GDP during 1995-2020. After the 2000-2002 dzud, the production of agricultural sector decreased from 37 percent in 1999 to 20.7 percent in 2002 which was 44 percent decrease. During 2000-2002, the annual GDP growth rate of agriculture sector was negative and annual GDP growth rate was mostly unchanged. The production of agricultural sector was relatively stable between 2003 and 2009. However, after the dzud of 2009-2010, it decreased from 17.9 percent in 2009 to 11.6 percent in 2010 which was 35 percent decrease. In 2010, the GDP growth rate of agricultural sector was negative and GDP growth rate showed decrease. Even though, the average agricultural production was 40 percent during 19951999, after two times dzud, it decreased to 13 percent by the average of 2012-2016.

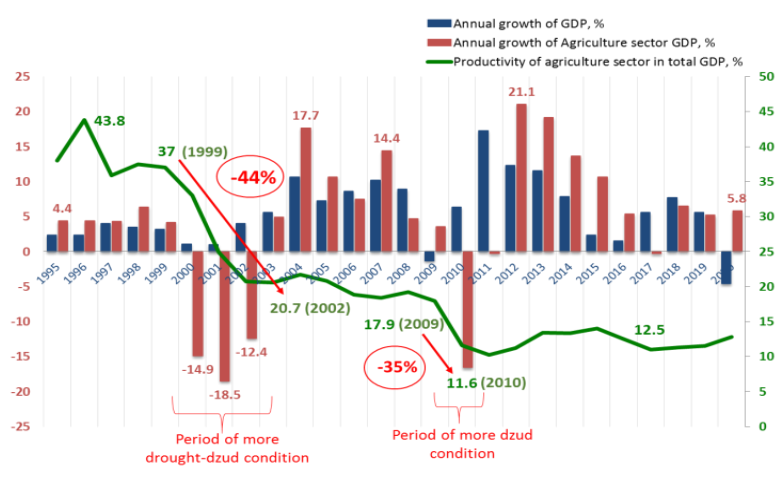

Figure 5. Annual growth of GDP and Agriculture sector, and Productivity of agriculture (1995-2020)

[9]

\subsection{Drought-Dzud impact on rural poverty and vulnerability}

During dzud, the livelihood of herder households are affected, unemployment and poverty increased. The damage of 1999-2002 drough-dzud is estimated to be over $\$ 90$ million, which is equal to $29 \%$ of the average agricultural production of 5 years at that time. Each herder's adaptive capacity is different depending on their geographical location, knowledge of traditional herding practices, and the number of livestock they own. Livestock sector is more vulnerable to climate change, herder households with up to 100 or 200 heads of livestock have been affected more by natural disasters. Moreover, poorer herder households with few livestock have less capacity to cope with dzud disaster [10]

Table 1 shows urban and rural poverty, number of herder households with up to 200 livestock and more than 200 livestock, before and after 1999-2002 and 2009-2010 dzud. In 2018, number of herder households with up to 100 livestock was 37.9 thousand and up to 200 livestock was 72.3 thousand which was 22.3 percent and 42.6 percent of total herder household respectively. After the dzud, the unemployment rate reached 4.6 percent in 2001 and poverty in rural area reached $43.4 \%$ in 2003 . It was 33 percent increase compared to 1998 . Herders losing their livestock are one of the reasons for intensified migration to urban areas.

Figure 6 shows poverty rate by settlements in 2003 and 2016. In 2016, poverty rate in the rural area was the highest (38 percent) followed by the soum center (32.3 percent). On the other hand, 34 percent of the total population lives in rural areas, 13 percent in soum centers, 21 percent in 21 aimag center and 45 percent lives in Ulaanbaatar. 
Table 1. Comparative analysis of damages in social and economic sector caused by dzud of 1999-2002 and $2009-2010[11 ; 12 ; 13 ; 14]$

\begin{tabular}{|c|c|c|c|c|c|c|c|c|}
\hline \multirow{4}{*}{$\begin{array}{l}\text { Grouping } \\
\text { households } \\
\text { livestock }\end{array}$} & \multirow{2}{*}{\multicolumn{4}{|c|}{ Drought-Zud condition during from }} & \multirow{2}{*}{\multicolumn{4}{|c|}{ Zud condition in winter of 2009-2010 }} \\
\hline & & & & & & & & \\
\hline & \multirow{2}{*}{1998} & \multirow{2}{*}{2003} & \multicolumn{2}{|c|}{ Gap $(-/+)$} & \multirow{2}{*}{2008} & \multirow{2}{*}{2011} & \multicolumn{2}{|c|}{ Gap $(-/+)$} \\
\hline & & & Number & Percent & & & Number & Percent \\
\hline $\begin{array}{l}\text { Less than } \mathbf{2 0 0} \\
\text { livestock }\end{array}$ & $232^{\prime} 645$ & $201^{\prime} 898$ & $-30^{\prime} 747$ & $\begin{array}{l}\text { Decreased } \\
\text { by } 13 \%\end{array}$ & $155^{\prime} 937$ & $165^{\circ} 043$ & $\begin{array}{l}+9 ' 106 \\
\end{array}$ & $\begin{array}{l}\text { Increased } \\
\text { by } 5 \%\end{array}$ \\
\hline $\begin{array}{l}\text { More than } \mathbf{2 0 1} \\
\text { livestock }\end{array}$ & $42^{\prime} 342$ & $34^{\prime} 312$ & $-8^{\prime} 030$ & $\begin{array}{l}\text { Decreased } \\
\text { by } 18 \%\end{array}$ & $71^{\prime} 610$ & $51^{\prime} 531$ & $-20^{\prime} 079$ & $\begin{array}{l}\text { Decreased } \\
\text { by } 28\end{array}$ \\
\hline $\begin{array}{l}\text { Total household } \\
\text { with livestock }\end{array}$ & $274^{\prime} 987$ & 236210 & $-38 ' 777$ & $\begin{array}{l}\text { Decreased } \\
\text { by } 14 \%\end{array}$ & $227 \times 547$ & $216^{\prime} 574$ & $-10^{9} 973$ & $\begin{array}{l}\text { Decreased } \\
\text { by } 4.8 \%\end{array}$ \\
\hline Urban & 39.4 & 30.3 & -9.1 & $\begin{array}{l}\text { Decreased } \\
\text { by } 23 \%\end{array}$ & 26.9 & 32.2 & +5.3 & $\begin{array}{l}\text { Increased } \\
\text { by } 19 \%\end{array}$ \\
\hline Rural & 32.6 & 43.4 & +10.8 & $\begin{array}{l}\text { Increased } \\
\text { by } 33 \%\end{array}$ & 46.6 & 47.8 & +1.2 & $\begin{array}{l}\text { Increased } \\
\text { by } 2.5 \%\end{array}$ \\
\hline
\end{tabular}

The poverty rate is higher in the rural areas and the soum centers, where 47 percent of the population lives. This indicates that significant numbers of people are at risk of losing their livelihood and poverty due to drought-dzud. Therefore, it is necessary to develop policies that increase climate change adaptive capacity and decrease vulnerability of the rural households with up to 200 livestock.
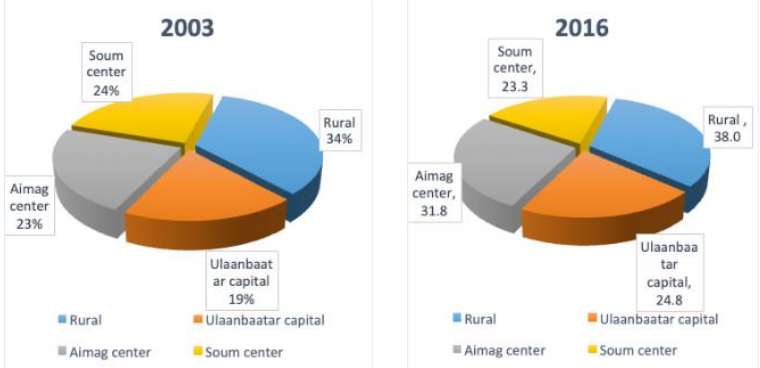

Figure 6. Poverty rate by settlement 2003 and 2016 [15]

\subsection{Drought-Dzud impact on migration to urban area}

22 percent of the population is working in the pastoral livestock sector and lives in rural areas. Figure7 shows the result of spatial analysis on changes of human settlements at the soum level. The population of Ulaanbaatar and 21 aimag centers are categorized as urban, 309 soum centers are categorized as soum center, and the rural population is categorized as rural. Annual average population growth rate is used in order to analyze the human settlement change. In 2003-2015, population of 4 urban areas decreased, but population increased in remaining 18 urban areas. On the other hand, the population of 166 soum centers and rural area of 215 soums decreased. This shows the decreasing trend in rural population, particularly the population working in pastoral livestock sector. In other words, main source of rural-to-urban migration is the rural population.

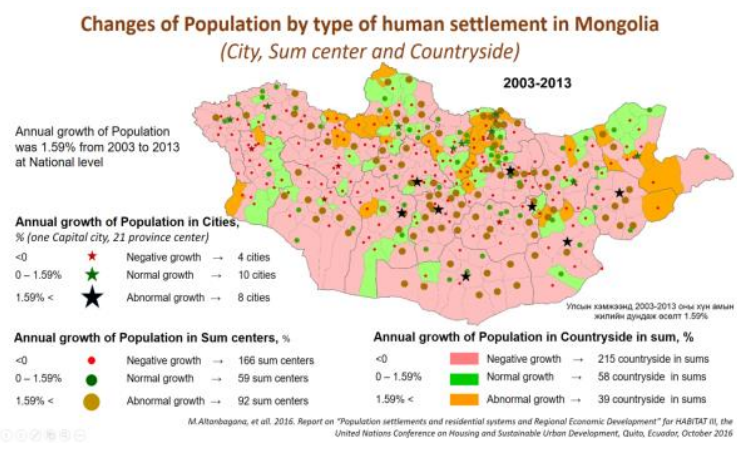

Figure 7. Changes of population and settlement type (city, sum center and countryside), 2003-2015 [8]

Figure 8 shows the number of herder households and number of people migrated to Ulaanbaatar in 1995-2019. At the national level, the migration to Ulaanbaatar was high in the years 2002, 2003, 2004, and 2010, which was after dzud occurrences. Assuming that a herder household has an average of 3.5 members, number of herder households who lost their livestock due to dzud (decreased by 22 thousand and 24 thousand household) is close to the number of people migrated to Ulaanbaatar city $(82.4+39.7)$ from rural areas.

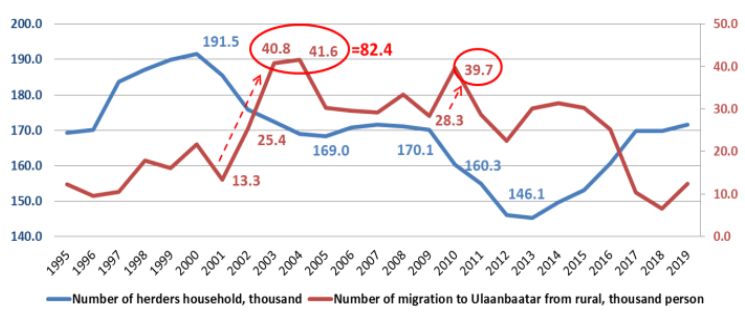

Figure 8. Number of herder household and number of migration from rural to Ulaanbaatar city

(1995-2019)

At the national level between 1995 and 2013, 480.7 thousand people moved to Ulaanbaatar from aimags and rural areas, which is equivalent to the population of four aimags. During the same period, 122.1 thousand people migrated to Ulaanbaatar city due to the 1999-2002 and 2009-2010 dzuds. This is 26 percent of the total migrants and can be defined as "climate refugees". In Mongolia, there is a strong connection between "climate change-poverty" and "climate change-migration" because of their unique life style, settlement, economic and ecosystem characteristics. 


\section{CONCLUSIONS}

In this study, impact of climate change on herder's livelihood, livestock loss, GDP growth in agriculture sector and migration in Mongolia was analyzed using national level socio-economic data and environmental data.

In 2000-2003, drough-dzud disaster affected over 90 percent of Mongolian territory and caused 11.17 million livestock loss. In 2009-2010, 80 percent of territory was affected and 10.32 million livestock were lost. The correlation coefficient of integrated

After the 2000-2002 dzud, the production of agricultural sector in total GDP decreased from 37 percent in 1999 to 20.7 percent in 2002 which was 44 percent decrease. After the dzud of 2009-2010, it decreased from 17.9 percent in 2009 to 11.6 percent in 2010 which was 35 percent decrease. Even though, the average agricultural production was 40 percent during 1995-1999, after two times dzud, it decreased to 13 percent by the average of 2012-2016. During dzud, the livelihood of herder households are affected, unemployment and poverty increased. After the dzud, the unemployment rate reached 4.6 percent in 2001 and poverty in rural area reached $43.4 \%$ in 2003. It was 33 percent increase compared to 1998. Herders losing their livestock are one of the reasons for intensified migration to urban areas. In 2016, poverty rate in the rural area was the highest (38 percent) followed by the soum center (32.3 percent). The poverty rate is higher in the rural areas and the soum centers, where 47 percent of the population lives.

In 2003-2015, population of 4 urban areas decreased, but population increased in remaining 18 urban areas. On the other hand, the population of 166 soum centers and rural area of 215 soums decreased. This shows the decreasing trend in rural population, particularly the population working in pastoral livestock sector. At the national level, the migration to Ulaanbaatar was high in the years 2002, 2003, 2004, and 2010, which was after dzud occurrences. Between 1995 and 2013, 480.7 thousand people moved to Ulaanbaatar from aimags and rural areas, which is equivalent to the population of four aimags. During the same period, 122.1 thousand people migrated to Ulaanbaatar city due to the 1999-2002 and 2009-2010 dzuds. This is 26 percent of the total migrants and can be defined as "climate refugees". In Mongolia, there is a strong connection between "climate change-poverty" and "climate changemigration" because of their unique life style, settlement, economic and ecosystem characteristics. dzud index and livestock loss during 1990-2014 was 0.69 , meaning there is a statistically significant relationship between the dzud occurrence and the livestock loss. This indicates that the dzud conditions are directly related to livestock loss. The number of herder households decreased by 22.5 thousand and 24 thousand during 1999-2002 and 2009-2010 dzud respectively. After the occurrence of two times dzud, in 2012, number of herder households decreased to 146.1 thousand which is $13 \%$ of total households. Decreased number of herders implies that dzud has significantly negative impact on herder livelihood and agricultural production.

\section{ACKNOWLEDGMENTS}

The researchers sincerely thank the Institute of Geography and Geoecology, Mongolian Academy of Sciences and colleagues for supporting the research work.

\section{REFERENCES}

[1] Ministry of Environment and Tourism of Mongolia, Mongolia Second Assessment Report on Climate Change, Ulaanbaatar, 2014.

[2] Ministry of Environment and Tourism of Mongolia, Third National Communication of Mongolia, Ulaanbaatar, 2018.

[3] T.Chuluun, M.Altanbagana, D. Ojima, R.Tsolmon and B.Suvdantsetseg, "Vulnerability of Pastoral Social-Ecological Systems in Mongolia," in Rethinking Resilience, Adaptation and Transformation in a Time of Change, Switzerland, Springer International Publishing, 2017, pp. 73-88. DOI: https://doi.org/10.1007/978-3-319-50171-0_6

[4] T. Chuluun, Towards Green Civilization, Ulaanbaatar, 2014.

[5] D. Ojima, T.Chuluun and M.Altanbagana, "Vulnerability of Pastoral Social-Ecological System to Multiple Stressors," in Vulnerability of Land Sustems in Asia, Beijing, 2014, pp. 2740.

DOI: https://doi.org/10.1002/9781118854945.ch3

[6] M.Altanbagana, VULNERABILITY: Pastoral social-ecological systems, Ulaanbaatar: Soyombo press LLC, 2017.

[7] M. Altanbagana and B. Kherlenbayar, "Ecological Vulnerability Impact on Peverty and 
Migration in Mongolian," National Development Institute, Ulaanbaatar, 2015.

[8] M. Altanbagana, D. S., T. D. and K. B., "National Report: Mongolian Urban Development for HABITAT III" and "Current Situation of Human Settlement and Regional Development Trends," http://habitat3.org/wpcontent/uploads/Mongolia-HABITAT-IIIReport-25.04.2016-english-final.pdf, Ulaanbaatar, 2016.

[9] National Statistics Office, Mongolian Statistical Year Book, Ulaanbaatar, 2020.

[10] M.Altanbagana and S.Davaanyam, "Assessment of vulnerability of rangeland ecosystems," vol. №1(13), pp. pp. 74-85, 2012.
[11] Government of Mongolia, Ministry of Food, Agriculture and Light Industry, Lessons learned from the 1999-2001 dzud in Mongolia, Ulaanbaatar, 2003.

[12]D. Bayaraa and P. Damdin, An Overview of Occurried Disasters in Mongolia, Ulaanbaatar:: Admon printing press, 2006.

[13] Government of Mongolia, "Retrieved from Goverment news," 2010. [Online]. Available: http://www.open-government.mn/read-188.

[14] M. Altanbagana and S. Davaanyam, "Dynamic Relations between Climate Change, Migration, Poverty and Human Development. Research on Development of Mongolia," 2012.

[15] National Statistics Office, Mongolian Statistical Yearbook 2016, Ulaanbaatar: National Statistical Office printing press, 2016. 